\title{
PENINGKATAN KOMPETENSI BAHASA INGGRIS MASYARAKAT KURANG MAMPU DI KABUPATEN LOMBOK BARAT PROPINSI NUSA TENGGARA BARAT
}

\author{
Lukman', Asbah'2, Hijril3, Ramlah ${ }^{4}$, Nurdin $^{5}$ \\ ${ }^{1}$ Pendidikan Bahasa Inggris, Universitas Muhammadiyah Mataram, maofmi2009@gmail.com
}

\begin{abstract}
ABSTRAK
Abstrak: Tujuan kegiatan pengabdian pada masyarakat ini adalah untuk memberikan motivasi, rangsangan dan latihan Bahasa Inggris bagi masyarakat kurang mampu khususnya siswa-siswi yang sedang belajar di sekolah menengah pertama dan madrasyah Ibtidaiyah serta sekolah menengah kejuruan. Khalayak sasaran strategis dari kegiatan ini adalah siswa-siswi yang ada di lingkungan Desa Kekeri Kecamatan Gunungsari Kabupaten Lombok Barat yang berjumlah 40 orang yang diambil secara acak dari semua siswa-siswi yang ada di daerah itu. Kegiatan ini melibatkan dosen dan mahasiswa Bahasa Inggris Universitas Muhammadiyah Mataram yang tergabung dalam tim penyuluhan. Materi penyuluhan meliputi cara menggunakan tata bahasa yang benar (grammar), pidato (speech), Berbicara (speaking) and Membaca (reading) sebagai bagian yang terpenting dalam pelajaran bahasa Inggris. Metode yang diterapkan dalam kegiatan pengabdian ini adalah metode gambar tentang strategi belajar bahasa Inggris menggunakan 5 materi diatas. Berdasarkan pengamatan dan tanya jawab pada saat kegiatan dilaksanakan dan setelah kegiatan dilaksanakan, siswa khalayak sasaran sangat antusias dan bersemangat dalam mengikuti semua proses kegiatan mulai dari ceramah, tanya jawab serta latihan. Bahkan setelah kegiatan dilaksanakan beberapa siswa mengungkapkan keinginannya untuk mendaftarkan diri mereka pada Universitas Muhammadiyah Mataram untuk belajar dan akan tetap menjadikan pelajaran bahasa Inggris sebagai bahasa dunia.
\end{abstract}

Kata Kunci: Motivasi, MTs, SMK, Strategi

\begin{abstract}
The purpose of community service is to provide motivation, stimulation and practice of English for the underprivileged, especially students who are studying in junior high school and MTs and SMK. The strategic target audience of these activities are the students in the village of Kekeri, Gunungsari, West Lombok regency, amounting to 40 people drawn at random from all the students in the area. This activity involves lecturers and students of English Muhammadiyah University of Mataram who are members of the counseling team. Extension materials include how to use correct grammar (grammar), speech (speech), speaking (speaking) and Reading (reading) as the most important part in the English lesson. The method applied in this devotional activity is the method of drawing on the strategy of learning English using the above 5 items. Based on the observation and question and answer session at the time the activities were carried out and after the activities were implemented, the target audience students were very enthusiastic and enthusiastic in following all the activities process from lectures, questions and answers and exercises. Even after the activities were carried out some students expressed their desire to enroll them at the Muhammadiyah University of Mataram to study and will continue to make English lessons as the world's language.
\end{abstract}

Keywords: Motivation, MTS, SMK, Strategy

Riwayat Artikel: Diterima: 10-12-2017, Disetujui: 13-12-2017 


\section{A. LATAR BELAKANG}

Pentingnya penguasaan bahasa Inggris sebagai bahasa Internasional oleh seluruh lapisan masyarakat, tidak perlu dipertanyakan lagi. Bahasa Inggris sebagai bahasa dunia serta dipergunakan oleh lebih dari 350 juta pembicara asli. Disamping itu, bahasa Inggris merupakan bahasa pertama dan utama ilmu pengetahuan dan teknologi. Sehingga peran strategisnya sebagai medium untuk mentransfer IPTEK tak dapat disangkal. Dengan demikian, upaya untuk menggunakan berbagai media yang memungkinkan merupakan langkah yang senantiasa dipacu demi percepatan penguasaannya.

Selanjutnya, bahasa Inggris berperan strategis hampir dalam semua aspek kehidupan, seperti bahasa dalam perdagangan dan industri, juga bahasa dalam film dan musik. Itulah mengapa penguasaannya sangat diperlukan sebagai pengadaptasian diri dengan pergaulan internasional khususnya bagi generasi muda yang merupakan pelanjut estafet regenerasi bangsa. Disamping itu, sebagai bagian integral dari percaturan dunia internasional. Masyarakat indonesia juga dituntut untuk menemukan langkah-langkah kreatif demi terwujudnya kemampuan yang memadai. Salah satu upaya yang dilakukan untuk menguasai bahasa Inggris. Pemerintah sudah lama mewajibkan pengajarannya dari bangku SMP sampai perguruan tinggi, bahkan untuk wilayah tertentu pengajaran juga diberikan sejak dari SD. Hal ini tidak lain adalah langkah-langkah antisipatif yang menunjukan pentingnya kemampuan menggunakan bahasa tersebut sedini mungkin jika kemampuan dalam segala aspek kehidupan menjadi tujuan yang harus segera terwujud.

Pada prinsipnya, pengajaran bahasa Inggris bertujuan untuk membekali para siswa untuk bisa menggunakannya dalam berkomunikasi sehari-hari. Sehingga, orientasi pengajarannya hendaknya difokuskan pada upaya pencapai tujuan komunikatif tersebut. Namun demikian tujuan tersebut tidak selalu mudah untuk diwujudkan. Hal ini dapat dilihat dengan mudah pada mereka yang telah belajar bahasa inggris selama kurang lebih 6 (enam) tahun sejak SD ke SMP hingga tamat SMA belum menunjukan kemampuan untuk dapat berkomunikasi secara memadai. Kenyataan ini boleh jadi disebabkan oleh salah satunya metode pengajaran bahasa Inggris dibanyak sekolah selama ini terlalu berorientasi pada aturan dan bentuk bahasa (grammar) bukan pada fungsi bahasa tersebut sebagai media ekspresi diri.

Klaim tentang belajar bahasa Inggris hampir sama dengan matematika misalnya, menggambarkan betapa orientasi pengajaran telah menekankan pada aspek kognitif semata tanpa mempertimbangkan aspek efektif dan psikomotorik peserta didik. Dengan demikian, telah menjadi persoalan klasik bahwa belajar bahasa Inggris merupakan sesuatu yang sangat tidak mengairahkan (untuk tidak mengatakan menakutkan) karena tidak ditemukannya faktor-faktor yang menyenangkan (fun). Ini dikarenakan, sekali lagi, para siswa terlalu banyak disodorkan dengan aturan-aturan bahasa yang disampaikan dengan cara sangat formal dan tradisional yang sering menyebabkan kebosanan dan ketegangan dalam diri siswa juga guru yang mengajarkannya. Terlebih kesuksesan pembelajaran hanya diukur dengan keberhasilan kognitif mereka dalam menjawab soal-soal evaluasi. 
Salah satu langkah kreatif dan bisa menarik minat siswa untuk belajar yang dianggap dapat membantu pengguasaan bahasa Inggris dengan mudah dan cepat adalah belajar dengan menggunakan grammar, speaking, reading, vocabulary serta Pidato (speech) dalam menggunakan bahasa Inggris. Juga sangat efektif untuk mengusai kosa kata (vocabulary) serta tata bahasa (grammar) dengan konteks penggunaannya. Selain itu, Pidato (speech) adalah untuk menciptakan mental mereka sehingga tidak ada kata malu (shy) yang mampu membantu siswa untuk lebih cepat meemahami konteks penggunaan sebuah kata atau aturan tata bahasa karena siswa dapat langsung menginterpresentasikannya dari materi yang diberikan yang mereka lihat.

Materi-materi di atas memang bukan mata pelajaran baru dalam pengajaran bahasa Inggris tapi menggunaannya dalam pembelajaran selama ini kurang dioptimalkan. Oleh karena itu, dengan mengoktimalkan penggunaan tata bahasa yang benar dan baik maka akan menghasilkan pengajar yang memiliki mental yang kuat serta memiliki kualitas dalam menyongsong hari esok yang lebih cerah untuk pengajaran bahasa Inggris, sehingga kesan formal yang cendrung menegangkan dan sulit mulai tergeser menjadi aktifitas yang bisa dinikmati dan menyenangkan. Diharapkan dengan memperkenalkan model pengajaran bahasa Inggris seperti ini diharapkan menjadi inspirasi bagi para pelajar dan guru sekolah. Sasaran pengabdian ini untuk dapat menggunakan bahasa Inggris yang baik dan benar. Dengan demikian, kegiatan peningkatan kompetensi bahasa Inggris masyrakat kurang mampu secara memadai dapat tercapai dengan cara-cara yang menyenangkan dan bukan sebaliknya yakni membebani pembelajar.

\section{B. KAJIAN PUSTAKA}

Pengajaran bahasa Inggris sebagai bahasa asing di Indonesia telah lama dilakukan oleh pemerintah, termasuk mengupayakan strategi pengguasaannya secara memadai, melalui pengenalan beberapa metode dan pendekatan pengajaran yang terus mengalami pembaharuan demi tercapainya target pembelajaran yang diinginkan. Hal ini dapat difahami mengingat implementasi metode tertentu bukanlah jaminan terhadap keberhasilan proses belajar, mengajar, mengingat kompleksnya persoalan yang harus dapat di atasi pada waktu yang bersamaan. Salah satu hal yang harus diingat adalah bahwa anak pada saat waktu bersamaan. Salah satu hal yang harus diingat adalah bahwa anak (pembelajaran bahasa tidak cukup hanya dengan menguasai tata bahasa dari bahasa target. Namun harus pula dibarengi penguasaan aspek lain yang membuat pembelajaran menjadi menyenangkan. Karena belajar bahasa mengisaratkan pentingnya memahami bagaimana unsur-unsur contextual (nyata) dalam arti formal dan informal juga difahami secara saksama termasuk penting memahami bagaiman komunikasi seharus berlangsung secara harmonis (river, 1989, willis, 3000). Ini mengindikasikan bahwa sosialisasi bahasa dengan konteks penggunaannya menjadi bagia integral dalam belajar bahasa target.

Dikatakan pula bahwa dalam belajar bahasa asing harus disadari bahwa pembelajaran senantiasa mempelajari apa yang ada di sekitarnya. Oleh karenanya tidak berlebihan jika [4] menyatakan bahwa: 
"...one young people know more abaout what is going in the woulds what is being done with their world than any previous generation."

Hal ini menegaskan bahwa materi dan metode pembelajaran hendaknya disesuaikan dengan dunia pembelajar. Karena dengan begitu mereka akan lebih tanggap untuk merespon dan memiliki motivasi tinggi untuk memenuhi kebutuhannnya, dan pada gilirannya akan memudahkan tercapainya target pengajaran yang diinginkan.

Selanjutnya, menegaskan pentinngnya pengajaran dengan mempertimbangkan proses mengadaptasikan materi ajar terhadap hal-hal yang sehari-hari dialami dan dilakoni pembelajar. Sehingga belajar merasa tidak menjadi beban, tetapi lebih sebagai persoalan mentrasfer sesuatu yang laxim dan ditemukan sehari-hari hanya dengan mengunakan bahasa yang berbasis itulah alasannya mengapa materi ajar sesungguhnya sangat perlu menekankan hal-hal yang telah diketahui dan menyenangkan sebagai langkah awal, baru kemudian dilanjutkan dengan hal-hal yang menjadi target kurikuler. Menghubungkan kehidupan siswa sehari-hari dengan materi ajar merupakan pendekatan yang dianggap efektif karena tidak menimbulkan beban, malah justru sebaliknya menimbulkan sesuatu yang menyenangkan.

Bahasa Inggris sebagai bahasa Asing (foreign language) yang dipelajari di Indonesia, disamping bahasa asing lainnya, telah mendapatkan perhatian serius dari pihak pemerintah untuk terus diupayakan mengembangkan dan pengajaran secara memadai, namun tidak sedikit kendala yang dihadapi. Salah satu kendala yang sering dijadikan alasan adalah minimnya fasilitas belajar. Pada hal jika guru kreatif maka banyak hal yang semestinya dapat dijadika sumber belajar. Menggunakan media gambar yang sederhana yang sering dilihat siswa misalnya merupakan salah satu langkah kreatif untuk memberikan motivasi pembelajar untuk dengan mudah mengikuti proses pembelajaran yang sedang berlangsung. Karena penggunaan media gambar dalam pembelajaran bahasa Inggris merupakan salah satu metode yang diharapakan dapat mengurangi beban para siswa dalam belajar. Gambar bisa membantu menciptakan suasana rilek, tidak stres dan menyenangkan [2].

Disamping itu, dalam gambar (pictures) banyak hal yang dapat dipelajari pembelajar disamping nilai hiburan yang didapatkan. Misalnya, melalui gambar, siswa tidak hanya sedang belajar menerjemahkan apa yang ada pada gambar tetapi pada saat yang sama mereka juga bisa melakukan keterampilan (skil)l bahasa yang lain yaitu berbicara (speaking) dengan mencoba menyebutkan apa yang mereka lihat di gambar, dan salah satu hal yang menarik yang dapat siswa lakukan melalui gambar adalah mendeskripsikan benda-benda atau orang yang ada di gambar. Keterampilan (skill) berbahasa ini dapat dilakukan dalam bentuk kelompok, berpasangan ataun individual tergantung situasi dan kondisi kelas.

Pengabdian ini mencoba memadukan antara sesuatu yang lazim kutemukan sehari-hari, yakni melihat dan menerjemahkan gambar yang mengandung unsur rekreatif dipadukan dengan unsur inovatif sebagai salah satu bentuk penyadaran terhadap sumber belajar yang murah meriah namun memiliki daya ungkit yang tinggi untuk memotivasi siswa dalam menmingkatkan kemampuan berbahasa Inggris, pengabdian ini dilakukan 
pada masyarakat kurang mampu yakni siswa dan siswi SMP/MTs dan SMA/SMK/MA sebagai masyarakat yang tinggal di Desa Kekeri Kecamatan Gunungsari Kabupaten Lombok Barat dengan pertimbangan bahwa memiliki potensi untuk berkembang lebih cepat dan memiliki kompetensi bahasa asing sekiranya mereka di fasilitasi dengan informasi yang memadai. Dengan demikian belajar merupakan proses yang mendatangkan kesenangan dan bukan beban.

\section{METODE PELAKSANAAN}

\section{Khalayak dan Strategis}

Khalayak sasaran dalam kegiatan pengabdian ini adalah siswa dan guru Madrasah Mahdania Kelurahan Jempong baru Kecamatan Sekarbela Kota Mataram. Sekolah ini dianggap relevan sebagai tempat pengabdian mengingat sekolah ini adalah sekolah swasta dan berdiri atas swadaya masyarakat, oleh karena itu, diperlukan kreatifitas guru untuk menyiasati cara belajar dengan menggunakan alat bantu yang murah dan menarik untuk menarik siswa belajar.

\section{Keterkaitan}

Kegiatan ini sangat erat kaitan dengan proses belajar mengajar khususnya dalam meningkatkan motivasi siswa dan memfasilitasi siswa untuk menguasai bahasa Inggris dengan cara lebih santai dan lebih menyenangkan jauh dari kesan formal, atau kaku dan menegangkan.

\section{Peserta dan Waktu Pelaksanaan Kegiatan}

Jumlah peserta mengikuti kegiatan peningkatan kompetensi bahasa Inggris ini adalah masyarakat yang kurang mampu yang tinggal di desa kekeri kecamatan gunungsari kabupaten lombok barat propinsi nusa tenggara barat, kegiatan ini dibiayai secara swadaya bersama antara dosen dan kepala desa, sampel pengabdian ini berjumlah 40 orang yang di ambil secara acak dari beberapa tingkatan sekolah yang ada. Kegiatan ini dilaksanakan selama 3 bulan dan kegiatan di mulai pada tanggal 1 April 2017 sampai 30 Juni 2017, kegiatan di mulai pada pukul 15.00 sampai 17.30 .

\section{Pelaksanaan}

Kegiatan pada masyarakat ini dilaksanakan dalam bentuk ceramah dan latihan belajar bahasa Inggris dengan menggunakan media gambar dilakukan oleh tim pengabdian dan siswa yang menjadi sasaran kegiatan. Kegiatan dimulai dengan ceramah tentang cara baru dan menyenangkan dalam belajar bahasa Inggris dengan menggunakan gambar serta ceramah tentang strategi memilih gambar yang tepat untuk dapat berbahasa Inggris. Kegiatan ceramah ini diberikan secara bergantian oleh tim penyuluh kegiatan. Kegiatan ceramah ini dilanjutkan dengan tanya jawab seputar cara memanfaatkan gambar sebagai sumber pembelajaran dan strategi memilih gambar yang tepat yang bisa digunakan untuk meningkatkan bahasa Inggris mereka. Setelah itu, dengan dipandu oleh tim pengabdian siswa berlatih belajar bahasa inggris menggunakan gambar. Dalam pengabdian kali ini, kegiatan pengajaran dikhususkan pada pengajaran adverb of place (kata keterangan tempat) menggunakan beberapa preposition (kata depan). Oleh karena itu, kegiatan ini difokuskan pada pemahaman siswa 
terhadap cara menggunakan adverb of place. Kegiatan penyuluhan dan pengajaran ini dilaksanakan dalam beberapa tahap, sebagai berikut:

\section{a. Preactivity (kegiatan awal)}

Dalam tahapan ini siswa diperlihatkan sebuah gambar melalui LCD projector dan diminta untuk menginterprestasikan apa yang mereka lihat pada gambar tersebut melalui dari setting pada gambar tersebut, nama-nama benda di gambar, orang-orangnya, apa yang sedang dilakukan orang-orang pada gambar tersebut, perbedaan antara benda atau orang dengan yang lainnya. Setelah itu, kegiatan akan dilanjutkan pada tahap selanjutnya, yaitu pada tahap inti kegiatan (while activity).

\section{b. While Activity (Kegiatan Inti)}

Dalam tahapan ini, siswa dibagikan dalam satu lembar kerja berisi kalimat-kalimat yang tidak lengkap dimana siswa nantinya harus mengisinya. Dalam lembar kerja telah disediakan beberapa preposition (kata depan) seperti on, in, under, above, between, in front of, behind, beside, dll. Siswa diminta mengisi kalimat-kalimat tersebut dengan melihat posisi benda atau orang yang ada di gambar tadi. Latihan pertama yang berjumlah 10 (sepuluh) kalimat diselesaikan secara lisan dengan menanyakan kepada siswa satu persatu. Kemudian, latihan kedua dikerjakan secara berpasangan dimana siswa akan dibagi menjadi siswa A (student A) dan Siswa B (student B). Di kegiatan ini siswa A dan siswa B diberikan gambar yang berbeda. Secara bergantian, siswa A menjelaskan letak benda atau orang yang ada pada gambarnya kemudia siswa B mengambarnya dikertas kerja yang sudah disediakan. Selanjutnya juga demikian, siswa B menjelaskan letak benda atau orang yang ada pada gambar kemudian siswa A menggambarnya dikertas kerja yang sudah disediakan pula. Setelah mereka menyelesaikannya, mereka menyesuaikan dengan gambar aslinya. Apabila ada kesalahan maka siswa tersebut memperbaikinya.

\section{HASIL DAN PEMBAHASAN}

Berkat dukungan semua pihak kegiatan pengabdian pada masyarakat ini dapat berjalan dengan baik sesuai dengan yang direncanakan. pihak perguruan tinggi khususnya universitas muhammadiyah mataram merasa bahwa kegiatan semacam ini perlu terus dilaksanakan untuk memotivasi dan memberikan masukan kepada guru untuk terus berinovasi dalam menciptakan metode-metode baru dan kreatif untuk mengajar guna mencapai target pembelajaran yang diharapkan. Siswa juga perlu mendapatkan materi dan metode belajar yang lebih menyenangkan dan tidak monoton sehingga mereka termotivasi untuk terus meningkatkan prestasi belajar mereka.

Selama kegiatan berlangsung siswa sebagai khalayak sasaran sangat antusias menyimak ceramah yang diberikan serta berpartisipasi penuh dalam kegiatan tanya jawab. Selama kegiatan latihan berlangsung siswa menyukai gambar yang diberikan karena gambar-gambar tersebut lucu dan menarik serta membantu mereka untuk mengingat kata-kata dengan mudah. Pengalaman dan pengetahuan yang didapatkan dari kegiatan ini 
dirasakan sangat bermanfaat bagi siswa untuk meningkatkan prestasi belajar masyarakat khususnya bahasa Inggris. Mereka merasa menemukan suatu pengalaman belajar yang berbeda, lebih menyenangkan dan tidak menegangkan seperti biasa mereka alami ketika mereka belajar bahasa Inggris di kelas.

Dari hasil pengamatan dan tanya jawab pada saat kegiatan dan setelah kegiatan dilaksanakan, siswa khalayak sasaran sangat senang dan bersemangat dalam mempelajari bahasa Inggris dengan metode ini. Menyatakan diri akan mempraktekan strategi yang diajarkan dirumah. Dengan demikian, siswa berharap dengan belajar bahasa Inggris melalui gambar, mereka dapat meningkatkan keahlian mereka dalam berbahasa Inggris (listening, writing, dan speaking) sehingga dapat disimpulkan bahwa pada kegiatan pengabdian pada masyarakat ini telah tercapai keberhasilan dan terlepas dari dukungan dan kerjasama yang baik antara pelaksana kegiatan dan sasaran khalayak strategis.

Masyarakat di Desa Kekeri merasa senang dan bangga atas kegiatan pengabdian masyarakat yang dilakukan oleh tim pengabdian universitas muhammadiyah mataram ini untuk menunjang kemampuan mereka dalam berbahasa Asing khususnya bahasa Inggris mengingat daerah ini sangat tinggi peminat untuk mencari kerja di luar negeri. Hal senada juga disampaikan oleh kepala desa bahwa kegiatan semacam ini harus terus berkelanjutan demi meningkatkan generai ke depan menjadi generasi emas 2045.

\section{E. SIMPULAN DAN SARAN}

Dari pelaksanan kegiatan pengabdian pada masyarakat dapat ditarik kesimpulan sebagai berikut:

\section{Kesimpulan}

a. Kegiatan pengabdian pada masyarakat yang dilibatkan 40 (empat puluh) orang masyarakat yang kurang mampu yang tinggal di Desa Kekeri Kecamatan Gunungsari Kabupaten Lombok Barat, mereka adalah siswa-siswi yang sedang menempuh pendidkan pada tingkat SMP/MTs dan SMA/MA/SMK ini berjalan dengan baik sesuai dengan tujuan yang diharapkan. Hal ini terlihat dari antusias para siswa khalayak stategis dalam mengikuti kegiatan baik dalam kegiatan ceramah maupun prakteknya (latihan). Keberhasilan ini juga terlihat dengan keinginan masyarakat dalam terus mencoba mencari gambar-gambar yang menarik dan tepat untuk belajar bahasa Inggris sehingga dapat meningkatkan kompetensi berbahasa Asing khusunya bahasa Inggris.

b. Dari hasil evaluasi lisan yang diadakan pada akhir kegiatan dan berdasarkan pengamatan selama kegiatan berlangsung, siswa khalayak sasaran telah memperoleh pengetahuan sekaligus pengalaman baru dalam mempelajari bahasa Inggris. Pengalaman baru dianggap sangat inovatif karena menjauhkan siswa dari kesan belajar yang kaku dan monoton serta menegangkan. 


\section{SARAN}

a. Walaupun penggunaan gambar dalam pembelajaran bahasa Inggris tidak tergolong baru, tetapi pelaksanaannya perlu lebih dioptimalkan karena hasil yang diperoleh lebih maksimal.

b. Mengingat pentingnya kreativitas dan inovasi baru dalam belajar, maka sangat diharapkan kepada para guru untuk terus meningkatkan kreatifitas mengajarnya baik itu dari segi materi maupun metode tanpa harus terbentur dengan keterbatasan fasilitas.

c. Kegiatan semacam ini harus ditindaklanjuti secara berkelanjutan (continue) dan terus di dukung sebagai wadah promosi murah sehingga penggusaan bahasa Inggris sebagai bahasa utama dunia dapat dioptimalkan.

\section{DAFTAR RUJUKAN}

[1] Anonim, Undang-undang No. 14 Tahun 2005 tentang Guru dan Dosen. Black, mary. S 3000. the geography of conection: bringing the world to students. In social Education; 64.4. Wilson Education Abstract. pp.354-358.

[2] Leith, william. D. 1979. Advanced french conversation throught popular music and pictures. The french review 52: pp. 537-551.

[3] Prevos, Andre, J. M. 1993, The new french popular music in the foreign language classroom, Conversation, culture, Americanisation in dimension: Language 92-93. pp. $25-41$.

[4] Rivers, wilga, M. 1989. Communicating naturally in a second language. Cambridge teaching Library.

[5] Willis, Arlette, I. 3000. Keeping in real Teaching and learning about culture, literacy, and respect. In English Education; 42,4. Wilson Education Abstracts. pp. 267-277.

\section{DOKUMENTASI KEGIATAN}
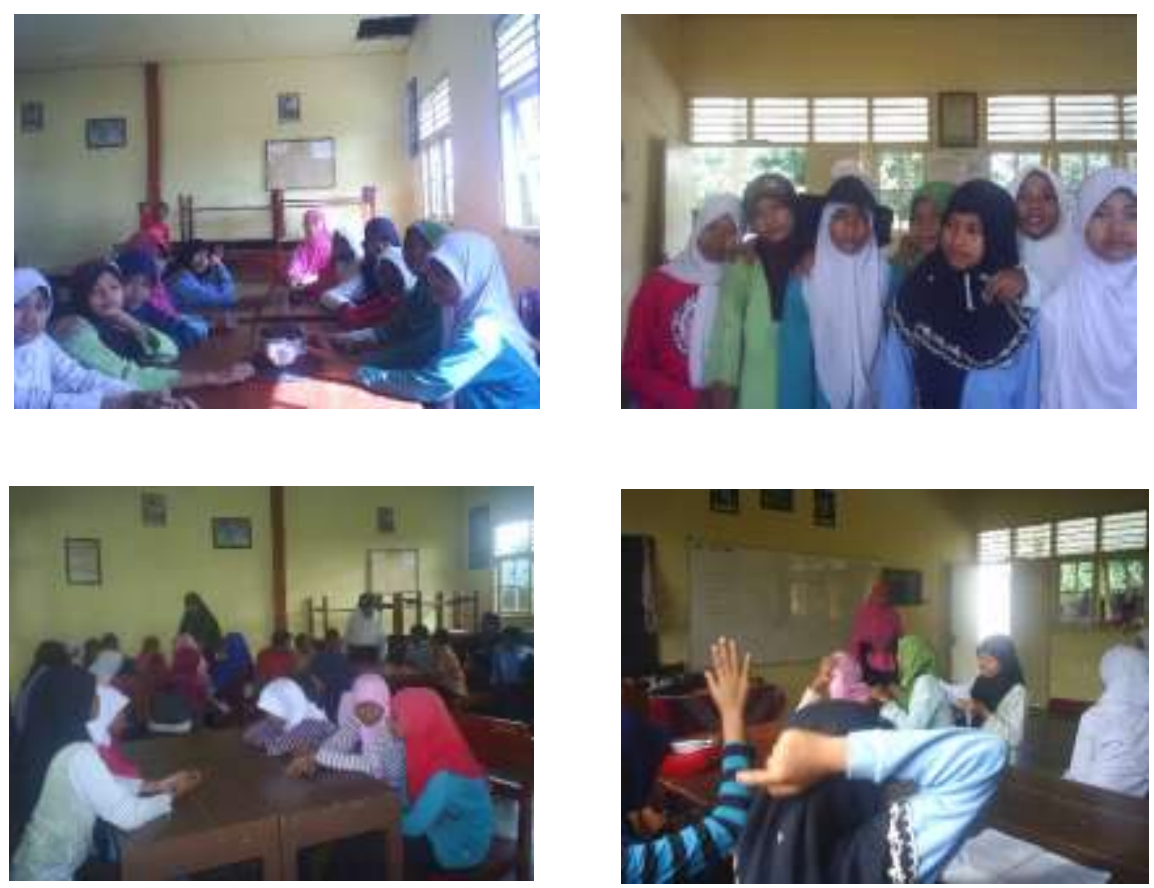